\title{
Parotid salivary mucocele in a companion rabbit (Oryctolagus cuniculus): a report on the clinical and laboratory characteristics and surgical treatment - case report
}

\author{
[Mucocele salivar parotídea em coelho doméstico (Oryctolagus cuniculus): relato de características \\ clínico-laboratoriais e tratamento cirúrgico - relato de caso] \\ S.T. Araujo $^{1}$, S.D.E. Campos $^{1}$, J.C.A. Ferreira ${ }^{2}$, A.S. Garrot ${ }^{3}$, L.A.S.L. Almeida ${ }^{4}$, \\ D.M. Cunha ${ }^{1}$, J.M.S. Barbosa ${ }^{1}$, N.R.P. Almosny ${ }^{4}$ \\ ${ }^{1}$ Aluno de pós-graduação - Universidade Federal Fluminense - Niterói, RJ \\ ${ }^{2}$ Centro Universitário Anhaguera - Niterói, RJ \\ ${ }^{3}$ Autônomo - Niterói, RJ \\ ${ }^{4}$ Faculdade de Veterinária - Universidade Federal Fluminense - Niterói, RJ
}

\begin{abstract}
The present report aimed to describe the main characteristics of the parotid salivary mucocele in an adult male rabbit, which presented with a painless fluctuating mass with fluid content. Owing to the need for repeated fluid drainage, surgical excision was the chosen mode of treatment. Preoperative evaluation included radiography and blood analysis. The patient underwent surgical excision of the affected gland. Inhalation anesthesia was maintained by means of isoflurane and the cardio-respiratory parameters were monitored throughout the surgery. A bipolar electrocautery was used to assist in the incision and polyglactin 910 and nylon were the suture materials used in the wound closure technique. Post-operative medications included analgesics, anti-inflammatory agents and antibiotics. Histopathology of the excised glandular tissue revealed a mixed inflammatory infiltrate, fibroblasts, hemorrhage and hyperemia. The observations in this case suggest that surgical excision of the affected gland is the treatment of choice for the management of mucocele in companion rabbits, which has already been identified for other animals. Periodic acid-reactive Schiff staining confirmed the diagnosis of salivary mucocele. The complementary investigations helped to rule out the differential diagnosis and indicated a favorable prognosis, in view of the fact that the case was successfully resolved without complications or recurrence.
\end{abstract}

Keywords: salivary glands, Lagomorpha, cytopathology, histopathology, surgery

\section{RESUMO}

O presente relato teve como objetivo descrever as principais características da mucocele salivar parotídea em um coelho macho adulto, que apresentou uma massa flutuante indolor e com um conteúdo líquido em seu interior. Devido à necessidade de repetidas punções deste fluido, optou-se pela excisão cirúrgica como forma de tratamento. A avaliação pré-operatória incluiu radiografias e análises sanguíneas. O paciente foi submetido ao tratamento cirúrgico com excisão da glândula afetada. A anestesia inalatória foi mantida com isoflurano e os parâmetros cardio-respiratórios foram monitorados durante a cirurgia. Um eletrocautério bipolar foi utilizado para auxiliar na incisão e os fios poliglactina 910 e nylon foram utilizados na técnica de sutura. As medicações pós-operatórias incluíram agentes analgésicos, anti-inflamatórios e antibióticos. A histopatologia do tecido glandular removido revelou infiltrado inflamatório misto, fibroblastos, hemorragia e hiperemia. As observações neste caso sugerem que a remoção cirúrgica da glândula afetada seja o tratamento de escolha no manejo da mucocele em coelhos de companhia, o que já vem sendo identificado para outros animais. A coloração do ácido periódico reativo de Schiff confirmou o diagnóstico da mucocele salivar. Os exames complementares ajudaram a excluir as doenças que fazem parte do diagnóstico diferencial e indicaram um prognóstico favorável, tendo em vista o fato que este caso foi resolvido com sucesso, sem complicações ou recorrência.

Palavras-chave: glândulas salivares, Lagomorpha, citopatologia, histopatologia, cirurgia

Recebido em 15 de janeiro de 2020

Aceito em 28 de agosto de 2020

E-mail: sabrinavet.silvestres@yahoo.com.br 


\section{INTRODUCTION}

Salivary mucocele is one of the most common causes of submandibular gland enlargement, in addition to other factors like sialolithiasis, sialadenitis or neoplasia (Spangler and Culbertson, 1991). It often presents as a painless benign cystic disorder, characterized by the collection of mucoid saliva in the soft tissue spaces adjacent to the gland, subsequent to an inflammation or injury (Spangler and Culbertson, 1991; Ritter et al., 2006).

Although previous studies have suggested that foreign bodies and trauma are the main etiologic factors of salivary mucocele in dogs, especially after surgical procedures, bite wounds or the extensive use of training leads and collars, the true etiology of salivary mucocele still remains ambiguous (Spangler and Culbertson, 1991; Ritter et al., 2006). Research involving salivary glands play an important role in the perception of digestion and enzymatic activity. Despite the fact that rabbits have been widely used in veterinary and medical research, little is known about the salivary glands and associated pathologic diseases in rabbits (Al-Saffar and Simawy, 2014). Hence, the aim of the current study was to describe a case of salivary mucocele in a companion rabbit, highlighting the main clinical and laboratory features of the disease, as well as the surgical treatment and recovery of the patient.

\section{CASE REPORT}

An adult male rabbit (Oryctolagus cuniculus), two years and eight months of age, was referred by its owner for physical examination and presented with a swelling in the neck region (Figure 1A), which was first noticed two-months before and gradually progressed to the present stage. There was no previous history of trauma or illness. At the time of examination, weight $(1900 \mathrm{~g})$, temperature $\left(38.5^{\circ} \mathrm{C}\right)$, heart rate $(200$ beats per minute), and respiratory rate (50 breaths per minute) were observed to be normal.

Palpation of the affected region revealed a fluctuating mass that showed no signs of pain with fluid content, which was aspirated. The total volume of the aspirate was $20 \mathrm{~mL}$. Laboratory analysis of the aspirate revealed a serosanguinolent and odorless fluid with low cellularity. Cytology was consistent with the features of a cystic lesion, comprised of a sparse population of epithelial cells, heterophils and macrophages arranged in an amorphous eosinophilic background. Bacteria or neoplastic cells were not detected.

Subsequently, the same region swelled again, and an ultrasound examination was performed (Figure 1B), which revealed a well-defined rounded structure $(6.0 \times 2.7 \times 3.4 \mathrm{~cm})$, filled with a large volume of anechoic content (fluid) and multiple suspended granules. The overall ultrasonographic appearance of the gland was heterogeneous and suggestive of a sialocele.

Owing to the need for repeated fluid drainage, surgical excision of the salivary gland was the chosen mode of treatment. Thoracic radiographs in the lateral and dorsoventral positions showed no abnormalities. Complete blood count evaluation and serum biochemistry analysis revealed a low platelet count $\left(132 \times 10^{3} / \mu \mathrm{L}\right)$, increased heterophil count $(60 \%, 4,140 / \mu \mathrm{L})$ and increased levels of serum urea $(55 \mathrm{mg} / \mathrm{dL})$. The heterophil: lymphocyte ratio (H:L) was 1.8 .

The anesthetic protocol commenced with the intramuscular (IM) administration of xylazine $(2 \mathrm{mg} / \mathrm{kg})$ and ketamine $(20 \mathrm{mg} / \mathrm{kg})$, which promoted a mild sedative effect and enabled the placement of an intravenous (IV) catheter (24g). Anesthesia was induced by means of isoflurane (approximately 3\% inspired fraction), IV propofol $(4 \mathrm{mg} / \mathrm{kg})$ and IV midazolam $(0.3 \mathrm{mg} / \mathrm{kg})$. Lidocaine (10\%) was sprayed into the larynx and subsequently, the patient was intubated with a number 3 orotracheal tube that was connected to a semi-open device. Inhalation anesthesia was maintained using isoflurane (approximately 1.7\% inspired fraction). During the induction of anesthesia, the following parameters were monitored: rectal temperature, electrocardiogram, oxygen saturation, plethysmography, arterial blood pressure, end-tidal $\mathrm{CO}_{2}\left(\mathrm{ETCO}_{2}\right)$, capnography and anesthetic gas analysis (sidestream sensor). 


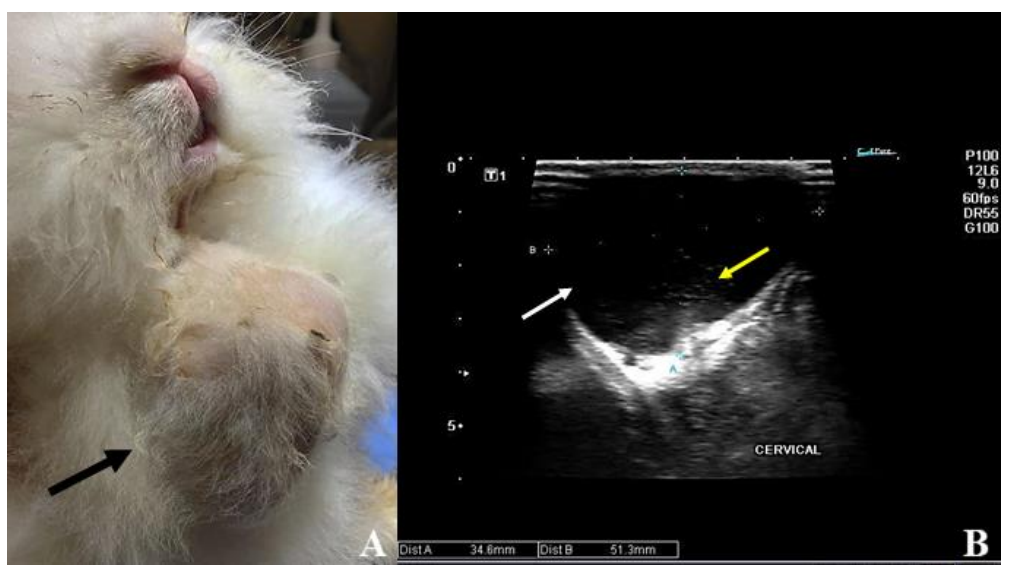

Figure 1. A: Photograph of the adult male rabbit (Oryctolagus cuniculus) with a swelling in the neck region (black arrow). B: Ultrasound examination showing a well-defined structure, filled with a large volume of anechoic content (white arrow) and suspended granules (yellow arrow).

The patient was positioned in the lateral decubitus position and a large trichotomy was performed until the cranial edge of the scapula, in order to perform the disinfection of the submandibular region using $2 \%$ chlorhexidine and $70 \%$ ethanol. A bipolar electrocautery was used to assist in the incision and dissection of subcutaneous tissue (Figure 2A). The surgical incision was made from the ventral border of the external auditory meatus, extending ventrally by two-thirds of the length of the neck. The auricular parotid muscle was deviated, exposing the parotid salivary gland (Figure 2B). Vessels were cauterized and the facial nerve was isolated in its ventral passage to the auditory canal and preserved. Subsequent to the glandular excision (Figure 2C), subcutaneous and skin closure were performed by means of the simple continuous suturing technique using polyglactin 910 and nylon suture materials, respectively (Figure 2D).

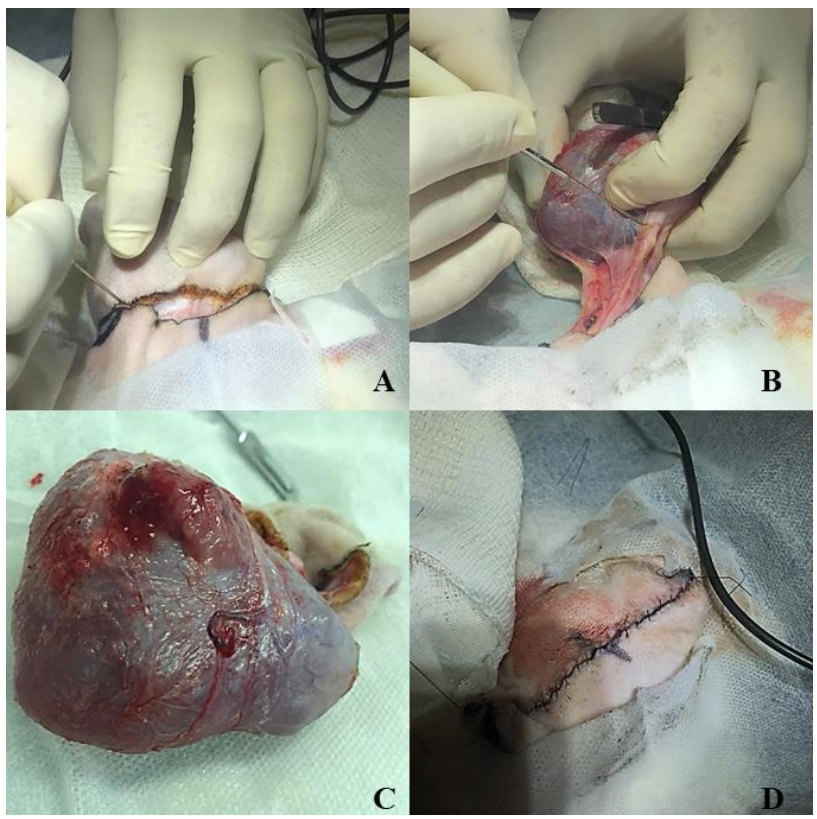

Figure 2. Stages of the surgical procedure of glandular excision, in order to treat the salivary mucocele in an adult male rabbit (Oryctolagus cuniculus). A: Submandibular region, isolated after trichotomy and the incision made using a bipolar electrocautery. B: Exposure of the enlarged parotid salivary gland. C: Macroscopic features of the parotid salivary gland after surgical excision. D: Appearance of the surgical wound after simple continuous suturing of the skin. 
Intravenous flumazenil $(0.1 \mathrm{mg} / \mathrm{kg})$ was used as a reversal agent for the recovery of the patient, which remained hospitalized for the initial 24 hours after the surgery and received postoperative medication as follows: IV tramadol every eight hours $(5 \mathrm{mg} / \mathrm{kg})$, subcutaneous meloxicam $(0.2 \mathrm{mg} / \mathrm{kg})$, IM enrofloxacin every 12 hours $(5 \mathrm{mg} / \mathrm{kg})$, and rifamycin spray on the surgical wound. Subsequent post-operative medications consisted of enrofloxacin $(5 \mathrm{mg} / \mathrm{kg})$ every 12 hours for 14 days, ibuprofen $(2 \mathrm{mg} / \mathrm{kg})$ every four hours for three days, both administered orally, and rifamycin spray on the surgical wound every 12 hours for 14 days. It was not necessary to use any devices to restrict or prevent the patient's access to the sutured area. The patient was fully recovered at the time of suture removal. The current study did not observe any complications or recurrence during one year of post-operative follow-up.
The excised gland, which had a smooth surface and a weight of $50 \mathrm{~g}$, was stored in a glass vial containing $10 \%$ buffered formalin solution, to be routinely processed for histopathological examination. Microscopic examination of the excised glandular tissue (Figure 3A-3C) revealed the presence of moderate mixed inflammatory infiltrate composed of lymphocytes, plasmocytes, macrophages and heterophils, surrounded by fibrous tissue composed of reactive fibroblasts. Moreover, histological evaluation showed discreet multifocal hemorrhage, perivascular inflammatory infiltrate of mononuclear cells (lymphocytes and plasmocytes) and severe hyperemia. Periodic acid-reactive Schiff (PAS) staining of the excised glandular tissue (Figure 3D) revealed purple-magenta granules, which confirmed the presence of carbohydrates. The aforementioned findings were consistent with the diagnosis of salivary mucocele.

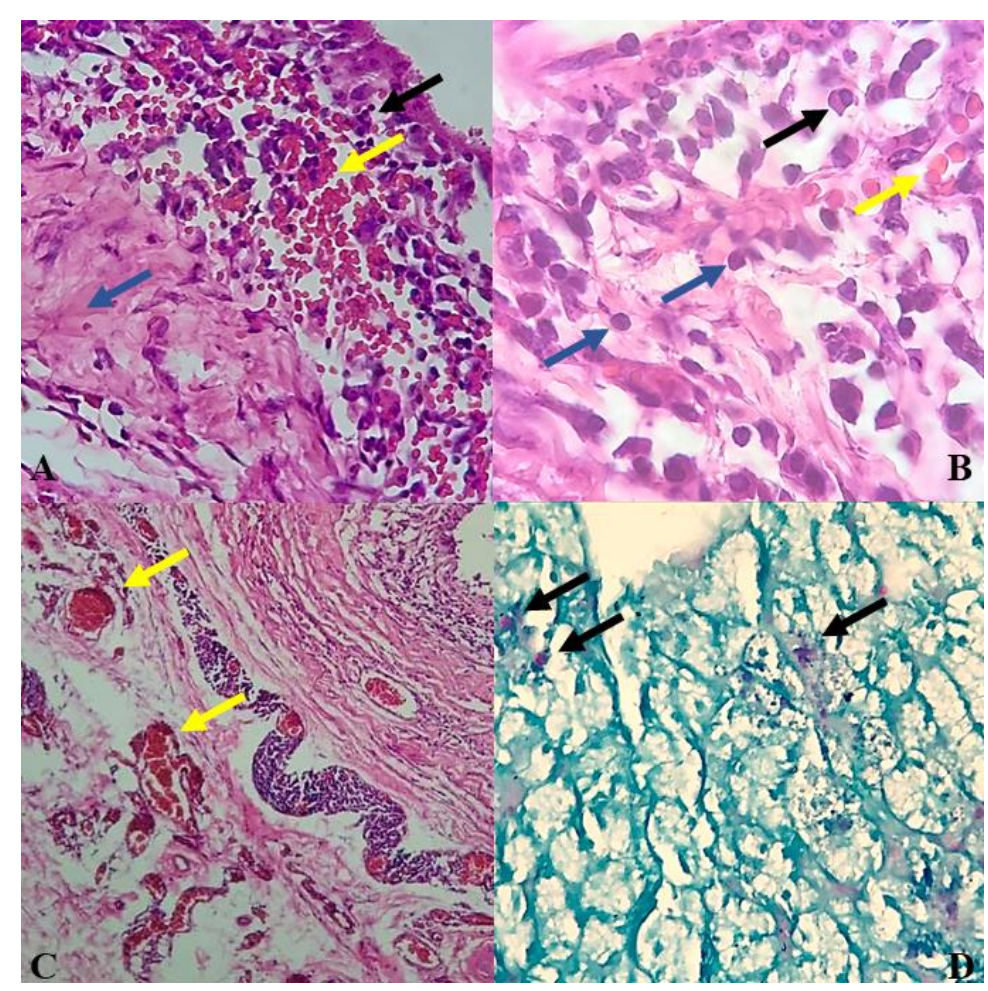

Figure 3. Photomicrographs of histopathological analysis of the parotid gland with salivary mucocele in an adult male rabbit (Oryctolagus cuniculus). A: Inflammatory infiltrate (black arrow) associated with hemorrhagic foci (yellow arrow), and fibrous connective tissue (blue arrow) (Hematoxylin-eosin staining - HE, obj.40x); B: Histological section showing the presence of erythrocytes (yellow arrow) associated with the inflammatory infiltrate of plasmocytes (black arrow) and lymphocytes (blue arrows) (HE, obj.100x); C: Perivascular inflammatory infiltrate and vessel hyperemia (yellow arrows) (HE, obj.10x); D: Histological section showing a positive PAS reaction, with purple-magenta granules (black arrows) (Periodic acid-reactive Schiff staining, obj.40x). 


\section{DISCUSSION}

In the present study, the rabbit presented no clinical symptoms other than a soft swelling in the neck region, which is similar to the clinical presentations reported in previous studies (Spangler and Culbertson, 1991; Kazemi et al., 2012). The current case report did not elucidate any causative factor for the disease, which corroborates the fact that it may be difficult to establish the etiology of salivary mucocele (Spangler and Culbertson, 1991). In dogs, foreign bodies and trauma are believed to be among the main causes of salivary mucocele and particularly relevant causative factors include surgical trauma and trauma ensuing from the continuous use of collars and biting (Spangler and Culbertson, 1991; Ritter et al., 2006).

Neoplasia and sialolithiasis should be considered in the differential diagnosis of mucocele. Generally, mucocele differs from neoplasia in their shape, consistency and symptoms. A previous study reported a case of salivary gland adenocarcinoma in a domestic rabbit and stated that the clinical behavior included head tilt, difficulty in mastication, lethargy and chronic wasting (Bercier et al., 2013). In the current study, the observations on ultrasonographic examination, which was useful in ruling out the differential diagnosis of sialolithiasis, was in agreement with the observations of a previous study by Torad and Hassan (2013), which reported the ultrasonographic characteristics of salivary mucoceles in dogs. According to the aforementioned authors, mucocele appears as a round structure, with a clearly identified wall and variable anechoic content, showing heterogeneous granulation.

In the present study, the elevation of serum urea levels was considered to be irrelevant, since its concentration is highly influenced by the circadian rhythm and improper management of the animal's diet, in addition to individual factors such as sex, age, exercise, nutritional status, and having a low sensitivity to kidney disease (Melillo, 2007). Heterophilia, with an increased $\mathrm{H}: \mathrm{L}$ ratio, may be associated with the stress of physical restraint and blood collection, along with the stress associated with the mucocele itself; since inflammatory processes constantly result in increased heterophils, even in the absence of left shift and leukocytosis. According to Melillo
(2007), the inflammatory response in rabbits is different from the other domestic species. In rabbits, leukocytosis is not the usual response to an inflammation and band neutrophils (or a left shift) are a rare finding.

Stressful situations such as transport, waiting in a room full of unfamiliar sounds and smells, pain and physical restraints can change the H:L ratio, especially if the rabbits are unfamiliar with the scenario. The H:L ratio is approximately 1:1 in an adult healthy rabbit, but in our patient, it was close to $2: 1$, which corroborates a possible relationship between stress and inflammation. Moreover, the patient displayed thrombocytopenia, which was possibly due to the inflammation. Recent studies indicate that platelets are involved in inflammatory or infectious diseases, either through an increase in the platelet consumption or through the formation of platelet-leukocyte aggregates, which leads to a decrease in the number of circulating platelets (Sonmez and Sonmez, 2017).

Similar to the observations in our case report, other authors have noted that the drainage of fluid provides a brief relief; however, subsequent gland excision is often required (Kazemi et al., 2012; Thas, 2014). Many factors must be considered in the post-operative recovery of an animal, regardless of its species. In the present report, veterinary recommendations were carefully adopted, and the post-operative wound healing was observed to be good, without any complications or recurrence of the disease. Previous studies have reported that the surgical approach to treatment has been successful in other animals, such as dogs and ferrets (Mustela putorius furo) (Fehr et al., 2006; Kazemi et al., 2012; Thas, 2014).

Previous studies have described the fluid cytology of zygomatic and mandibular salivary mucoceles in domestic ferrets and also reported a low cellularity with the presence of red blood cells, neutrophils, macrophages and epithelial cells in an eosinophilic background (Fehr et al., 2006; Thas, 2014). Previous studies have already established that the histology of the mucocele wall consists of an outer layer of connective tissue and an inner zone of a pleocellular inflammatory reaction, blood vessels, and occasional hemorrhages (Kazemi et al., 2012; Thas, 2014). 
These features were concurrent with observations in the current case report.

In the present study, the characteristics of malignancy were not observed; thus, emphasizing the difference between salivary mucocele and neoplasia, (Bercier et al., 2013). PAS is a staining method, mainly used to detect structures with a high proportion of carbohydrate, such as glycogen and muco substances. Similar to the observations in our study, a positive PAS reaction has been used to confirm the diagnosis of salivary mucocele in dogs and ferrets in previous studies (Kazemi et al., 2012; Thas, 2014).

To the best of the authors' knowledge, this is the first clinical, pathological and surgical description of a salivary mucocele of the parotid gland in a domestic rabbit. The only reference found on the mucocele in this species was reported by Li et al. (2010). These authors described the surgical removal of a polycystic mucocele in a rabbit kept as a laboratory animal in China, which presented with exophthalmia due to a mass located temporally to the optic nerve. A previous report by Gardhouse et al. (2016) described a case of sialectasis, which is the dilation of a salivary duct, in a rabbit from the USA.

The aforementioned disease is mainly caused by sialoliths, infection, polyps, foreign bodies and anatomic malformations. According to the authors, sialectasis differs from mucocele, owing to the fact that the extravasation of saliva into the glandular tissues is necessary for the latter to occur, although both result in a clinically apparent facial swelling. In this context, histopathology is the key to the differentiation between sialectasis and mucocele. While the salivary duct system is lined by epithelium (normal or inflamed), the wall of the mucocele is lined by fibroblasts, which is in agreement with the findings of the current study.

\section{CONCLUSION}

The present case report described the occurrence of a parotid salivary mucocele in a companion rabbit. Ultrasound examination ruled out the possibility of sialolithiasis. Cytology was important to rule out infection and malignancy. The results of a complete blood count evaluation suggested stress and inflammation. Mixed inflammatory infiltrate, fibrous connective tissue, perivascular mononuclear reaction, vessel hyperemia and hemorrhage, without any features of malignancy, were the important microscopic findings in the current study. A positive PAS reaction supported the diagnosis of salivary mucocele. Clinical, laboratory and pathological features indicated a favorable prognosis. Surgical removal of the parotid gland resulted in complete recovery of the patient without any complications or recurrence.

\section{ACKNOWLEDGMENTS}

The authors would like to extend gratitude to those who collaborated with the diagnostic support, especially the "LCV Flávia Uchôa" Veterinary Clinical Laboratory, "Gabriel Bobany - Cytopathology, Myelogram and Clinical Analysis", and the Veterinary Reference Center "CRV Imagem".

\section{REFERENCES}

AL-SAFFAR, F.J.; SIMAWY, M.S.H. Histomorphological and histochemical study of the major salivary glands of adult local rabbits. Int. J. Adv. Res., v.2, p.378-402, 2014.

BERCIER, M.; GUZMAN, D.S.M.; STOCKMAN, J. et al. Salivary gland adenocarcinoma in a domestic rabbit (Oryctolagus cuniculus). J. Exot. Pet Med., v.22, p.218-24, 2013.

FEHR, M.; THIELE, A.; G ERDWILKER, A. et al. Salivary mucocele (Zygomaticgland) in a ferret (Mustela putorius furo L.). Kleintierpraxis, v.51, p.210-215, 2006.

GARDHOUSE, S.; GUZMAN, D.S.M.; PETRITZ, O.A. et al. Diagnosis and treatment of Sialectasis in a domestic rabbit (Oryctolagus cuniculus). J. Exot. Pet Med., v.25, p.72-79, 2016.

KAZEMI, D.; DOUSTAR, Y.; ASSADNASSAB, G. Surgical treatment of a chronically recurring case of cervical mucocele in agerman shepherd dog. Case Rep Vet. Med., v.2012, n.8, 4p.2012.

Li, X.; Lu, Y.; Li, L. et al. Multi-channel visual evoked potential as an ancillary tool to diagnose intraorbital optic nerve lesions. Vet. Ophthalmol., v.13, p.131-135, 2010.

MELILLO, A. Rabbit Clinical pathology. J. Exot. Pet Med., v.16, p.135-145, 2007. 
RITTER, M.J.; VON PFEIL, D.J.; STANLEY, B.J. et al. Mandibular and sublingual sialoceles in the dog: a retrospective evaluation of 41 cases, using the ventral approach for treatment. $N$. Z. Vet. J., v.54, p.333-337, 2006.

SONMEZ, O.; SONMEZ, M. Role of platelets in immune system and inflammation. Porto Biomed. J., v.2, p.311-314, 2017.

SPANGLER, W.L.; CULBERTSON, M.R. Salivary gland disease in dogs and cats: 245 cases (1985-1988). J. Am. Vet. Med. Assoc., v.198, p.465-469, 1991.
THAS I. Acquired salivary mucoceles in two domestic ferrets (Mustela putorius furo). Vet. Rec. Case Rep., v.2, p.e000051, 2014.

TORAD, F.A.; HASSAN, E.A. Clinical and ultrasonographic characteristics of salivary mucoceles in 13 dogs. Vet. Radiol. Ultrasound, v.54, p.293-298, 2013. 